The following formula gives the quantities for 50 portions of $6 \mathrm{~g}$. each.

Sodium chloride $B . P$

Potassium chloride $B$.

Potassium phosphate B.P.C.

$5 \cdot 85 \mathrm{~g} \cdot$

$7 \cdot 46 \mathrm{~g}$ $1949 \quad \ldots \quad \ldots \quad$...

Potassium acid phosphate B.P.C. $1949 \quad \ldots \quad \ldots \quad 3.40 \mathrm{~g}$.

$\begin{array}{rllr}\text { Sodium gluconate } & \cdots & \ldots & 21.82 \mathrm{~g} .\end{array}$

$\begin{array}{lllll}\text { Dextrose } \ldots & \ldots & \ldots & 257 \cdot 11 \mathrm{~g} .\end{array}$

Prepare as granules. Pack in $6 \mathrm{~g}$. quantities.

6 g. of granules dissolved in $100 \mathrm{ml}$. boiled tap water produces a solution containing:

Sodium $\quad \cdots \quad 4.0 \mathrm{mEq}$.

Potassium ... 3.5 ,

Chloride ... 4.0 , $\begin{array}{ccccc}\text { Phosphate } & \ldots & 2 \cdot 0 & & \\ \text { Gluconate } & \ldots & 2 \cdot 0 & \text { " in } 5 \% \text { dextrose solution. }\end{array}$

Although the preparation is designed for babies, it would seem to have some value in certain cases of electrolyte replacement in adults. ${ }^{2}$ - I am, etc.,

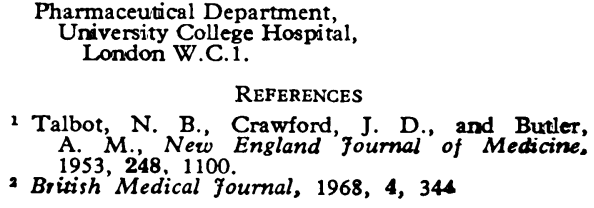

REFERENCES

2 Talbot, N. B., Crawfond, J. D., and Butler, A. M., New

British Medical fournal, 1968, 4, 344

\section{Suppression of Lactation}

SIR,-The reports by Daniel and his colleagues $^{1}$ and Professor T. N. A. Jeffcoate and others (5 October, p. 19), both suggesting that the suppression of lactation in the puerperium is associated with a higher incidence of thrombosis, prompted us to examine the evidence in this region. The case records of all women delivered in hospital in Aber- require the administration of anticoagulants. In the four years there were 14,754 cases for analysis, of whom $41 \cdot 2 \%$ were lactating.

Table I shows the number and percentage lactating at six days. The cases are divided by mode of delivery into spontaneous vaginal, assisted vaginal, and caesarean section cases. The lowest percentage lactating $(5.6 \%)$ was in

TABLE I.-Number of Mothers and Percentage Lactating at 6 Days

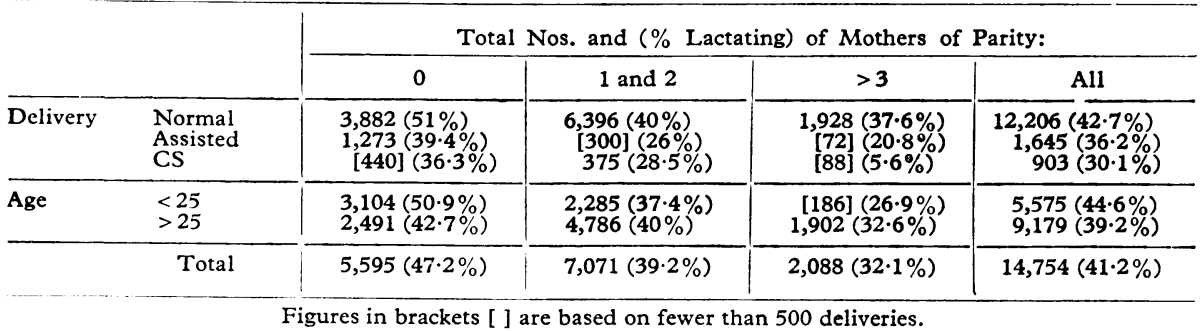

deen over a period of four years, from 1958 to 1961 inclusive, were examined.

Twin deliveries and stillbirths were excluded, as were those patients who were discharged before the sixth day of the puerperium. As in the Cardiff study, "thromboembolism" was defined as any case of pulmonary embolism or deep vein throm bosis which showed signs definite enough to

TABLE II.-Incidence of Thromboembolism

\begin{tabular}{|c|c|c|c|c|}
\hline & \multicolumn{4}{|c|}{$\begin{array}{c}\text { Nos. of Deep Vein Thromboses and } \\
\text { Incidence per } 100 \text { births in Mothers } \\
\text { of Parity: }\end{array}$} \\
\hline & 0 & 1 and 2 & $>3$ & All \\
\hline $\begin{array}{l}\text { Lactating . } \\
\text { Not lactating }\end{array}$ & $\begin{array}{r}9(3 \cdot 4) \\
13(4 \cdot 4)\end{array}$ & $\begin{array}{r}6(2 \cdot 2) \\
23(5 \cdot 3)\end{array}$ & $\begin{array}{c}6(8 \cdot 9) \\
21(14 \cdot 8)\end{array}$ & $\begin{array}{l}21(3.4) \\
57(6.6)\end{array}$ \\
\hline Total & $22(3.9)$ & $29(4 \cdot 1)$ & $27(12.9)$ & $78(5 \cdot 3)$ \\
\hline
\end{tabular}

those of high parity delivered abdominally. The total number of cases of thromboembolism was 78 , giving a rate of $5 \cdot 3$ per 1,000 deliveries, a figure comparable to that reported in Cardiff

TABLE III.-Variations of Incidence of Thromboembolism with Age, Parity, and Feeding

\begin{tabular}{|c|c|c|c|c|}
\hline & \multicolumn{4}{|c|}{$\begin{array}{c}\text { No. of Deep Vein Thromboses and } \\
\text { Incidence per } 100 \text { Births in Mothers } \\
\text { of Parity: }\end{array}$} \\
\hline & 0 & 1 and 2 & $>3$ & All \\
\hline $\begin{array}{l}\text { Age }<25 \\
\text { Lactating } \\
\text { Not lactating } \\
\end{array}$ & $\begin{array}{l}4(2 \cdot 5) \\
5(3 \cdot 3) \\
\end{array}$ & $\begin{array}{l}2(2.3) \\
5(3.5)\end{array}$ & $\begin{array}{l}0(0) \\
0(0)\end{array}$ & $\begin{array}{l}7(2 \cdot 8) \\
9(2 \cdot 9)\end{array}$ \\
\hline Total & $9(2 \cdot 9)$ & $7(3 \cdot 1)$ & $0(0)$ & $16(2.9)$ \\
\hline $\begin{array}{l}\text { Age }>25 \\
\text { Lactating } \\
\text { Not lactating }\end{array}$ & $\begin{array}{l}4(3.76) \\
9(6.3)\end{array}$ & $\begin{array}{r}4(2 \cdot 1) \\
18(6 \cdot 3) \\
\end{array}$ & $\begin{array}{r}7(11 \cdot 3) \\
20(15 \cdot 6) \\
\end{array}$ & $\begin{array}{r}14(3.2) \\
48(8.6) \\
\end{array}$ \\
\hline Total & $13(5 \cdot 2)$ & $22(4 \cdot 6)$ & $27(14 \cdot 2)$ & $62(6 \cdot 7)$ \\
\hline
\end{tabular}

TABLE IV.-Variations of Incidence of Thromboembolism with type of Delivery, Parity, and Feeding

\begin{tabular}{|c|c|c|c|c|c|}
\hline & Nos. of Deep & Vein Thromboses & and Incidence per & 1,000 Births in $N$ & Sothers of Parity: \\
\hline & & 0 & 1 and 2 & $>3$ & All \\
\hline \multirow[t]{2}{*}{ Normal delivery } & $\begin{array}{l}\text { Lactating } \\
\text { Not lactating } \\
\end{array}$ & $\begin{array}{l}8(4) \\
8(4 \cdot 2) \\
\end{array}$ & $\begin{array}{r}3(1 \cdot 1) \\
13(3 \cdot 4) \\
\end{array}$ & $\begin{array}{l}4(6 \cdot 1) \\
13(10 \cdot 2)\end{array}$ & $\begin{array}{l}15(2 \cdot 9) \\
34(4 \cdot 9)\end{array}$ \\
\hline & Total & $16(4 \cdot 1)$ & $16(2 \cdot 5)$ & $17(8 \cdot 8)$ & $49(4)$ \\
\hline \multirow[t]{2}{*}{ Assisted delivery } & $\begin{array}{l}\text { Lactating } \\
\text { Not lactating } \\
\end{array}$ & $\begin{array}{l}0(0) \\
2(2 \cdot 6) \\
\end{array}$ & $\begin{array}{l}{[1](12 \cdot 8)} \\
{[1](4 \cdot 5)}\end{array}$ & $\begin{array}{l}{[1](66 \cdot 6)} \\
{[0](0)}\end{array}$ & $\begin{array}{l}2(3 \cdot 4) \\
3(2 \cdot 8) \\
\end{array}$ \\
\hline & Total & $2(1 \cdot 6)$ & [2] (6.7) & [1] $(1 \cdot 4)$ & $5(3)$ \\
\hline \multirow[t]{2}{*}{ Caesarean section } & $\begin{array}{l}\text { Lactating } \\
\text { Not lactating }\end{array}$ & $\begin{array}{l}{[1](6 \cdot 2)} \\
{[3](10 \cdot 7)}\end{array}$ & $\begin{array}{l}{[2](18 \cdot 7)} \\
{[9](33.6)}\end{array}$ & $\begin{array}{l}{[1](200)} \\
{[8](96 \cdot 4)}\end{array}$ & $\begin{array}{l}{[4](14 \cdot 7)} \\
20(31 \cdot 7)\end{array}$ \\
\hline & Total & [4] $(9 \cdot 1)$ & [11] (29.3) & [9] $(102 \cdot 3)$ & $24(26)$ \\
\hline
\end{tabular}

Figures in brackets [ ] are based on fewer than 500 deliveries.

but greater than the incidence found in Liverpool. Table II shows the incidence of thromboembolism in lactating and non-lactating women by parity.

This Table should be read in conjuction with Table III. It can thus be seen on inspection that the puerperal woman's age is a much more important factor than her parity when the association of thromboembolism is considered, and this is confirmed by statistical analysis.

Applying a $\chi^{2}$ test to the raw data the difference in incidence of thromboembolism between lactating and non-lactating women is significant $(P<0.05)$. When, however, the figures are standardized for parity and method of delivery, then, although there is still a higher incidence of thromboembolism in non-lactating women than in those lactating, this difference is no longer significant $\left(x^{2}=2 \cdot 4166\right)$.

Table IV indeed shows the importance of operative delivery in this respect, in that 24 out of 78 cases occurred in women delivered by caesarean section.

These results suggest that operative delivery and age rank high among those factors associated with a high risk of puerperal thromboembolism which were examined, and suppression of lactation is probably much less important. We therefore share, on this evidence, the doubts expressed by Professor Jeffcoate and his colleagues concerning the importance of the administration of oestrogens in the aetiology of puerperal thrombosis. However, the dosage of stilboestrol used may be of some importance, as in this hospital a course consists in all of $80 \mathrm{mg}$., and this is certainly much lower than the dosage reported by Daniel et al. from Cardiff. We are, however, unlike Professor Jeffcoate, in some doubt concerning the effectiveness of oestrogens in the suppression of lactation. In a recent double-blind trial in this hospital Maclean ${ }^{2}$ could show only a slight difference in clinical effect between Mixogen $2 \mathrm{ml}$. (which contains ethinyloestradiol and methyl testosterone) and placebo in primiparae, and none at all in multiparous patients. However, as Professor Jeffcoate suggests, the prospective studies now being conducted in various centres should throw more light on what is at present a glimmer on the horizon. -We are, etc.

K. S. STEWART

D. F. KERRIDGE.

Department of Obstetrics and K. J. Dennis. University of Aberdeen.

\section{REFERENCES}

- Daniel, D. G., Campbell, H., and Turnbull, Maclean, M. W., personal communication.

\section{Degenerative Tropical Neuropathy and Diet}

SIR,-I read with great interest the report of a field survey by Dr. C. K. Osuntokun and colleagues ( 1 March, p. 547) in which the above relationship to cassava (manioc) consumption was suggested. It is interesting to edd $^{1}$ that manioc, a corruption of manihot by American and European usage, is of more recent arrival in Africa than the European, and was completely unknown outside the Americas before the voyages of Columbus, not unlike the history of the introduction of tea and tobacco in Great Britain. As Jones further showed in his monograph, it became 